plants, although chlorophyll itself does not contain this metal. $\delta$-Aminolævulic acid, however, is an intermediate of this biosynthetic process ${ }^{8}$. Further work on these observations is in progress and will be reported in full elsewhere.

I wish to thank Prof. C. Rimington for his interest and advice and Miss B. Knight for technical assistance during the course of this work, which was carried out during the tenure of an I.C.I. Research Fellowship.

\section{E. G. Brown}

Department of Chemical Pathology,

University College Hospital Medical

School,

London, W.C.1.

July 7.

${ }^{1}$ Brown, E. G., Biochem. $J$. (in the press).

- Pappenheimer, A. M., J. Biol. Chem., 167, 251 (1947).

"Schulman, M. P., and Richert, D. A., Fed. Proc., 15, 349 (1956).

4 Patwardhan, M. V., Nature, 181, 187 (1958).

${ }^{5}$ Duesberg, R., Klin. Wsehr., 17, 1353 (1938).

- Heilmeyer, L., and Plöttner, K., Klin. Wschr., 15, 1669 (1936).

"Lipmann, F., and Tuttle, L. C., J. Biol. Chem., 159, 21 (1945).

"Granick, S., "Porphyrin Biosynthesis and Metabolism", Ciba Symposium, 145, edit. by Wolstenholme, G. E. W., and Millar, E. C. P (Churchill, London, 1955).

\section{Effect of Copper Deficiency on Synthesis of Hæm}

Although copper is essential for the formation of normal hæmoglobin, it has not been demonstrated that this element functions directly in the synthesis of hæm. We have demonstrated an increased synthesis of hæm in vitro from glycine labelled with carbon-14, by means of adding inorganic copper to copper-deficient chicken blood.

Cross-bred chicks from a commercial hatchery were rendered deficient in copper in two weeks by feeding the following diet : non-fat milk solids, 55 per cent; glucose-monohydrate, 40 per cent; cotton-seed oil, 2 per cent; glycine, 0.6 per cent; L-arginine monohydrochloride, 0.5 per cent ; L-cystine, 0.2 per cent ; choline chloride, 0.6 per cent; and sodium chloride, 0.5 per cent. In addition, each $100 \mathrm{gm}$. of diet contained $2 \mathrm{mgm}$. of nicotinic acid, 240 I.U. of vitamin A-palmatate, $12.4 \mathrm{mgm}$. magnesium sulphate, $1.9 \mathrm{mgm}$. manganese sulphate and the equivalent of $14 \mathrm{mgm}$. carbonyl iron (General Aniline Works, Grasselli, New Jersey). The iron was fed in the carbonyl form in experiments 1,2 and 3 and in the chloride form in experiments 4,5 and 6 . The control diets were supplemented with $1.6 \mathrm{mgm}$. of copper sulphate per $100 \mathrm{gm}$. of diet. The criteria for deficiency in copper were reduced growth-rate and hæmoglobin concentration.

To determine the effect of a deficiency of copper on synthesis of hæm, $0.1 \mathrm{ml}$. of a solution of glycine containing 1 uc. methylene-labelled glycine and sufficient non-labelled glycine to yield a final concentration of $1.33 \times 10^{-2} M$ was added to either 3 or $5 \mathrm{ml}$. of heparinized whole blood. In addition, antibiotics ${ }^{1}$ and $0.1 \mathrm{ml}$. of a ferrous sulphate solution were added to yield a final concentration of $2 \times 10^{-4}$ $M$, as recommended by Dresel and Falk ${ }^{2}$. All samples were incubated at $37.5^{\circ} \mathrm{C}$. under an oxygen atmosphere in a Warburg apparatus for $24 \mathrm{hr}$. Hæm was isolated and recrystallized according to the method of Shemin et al. ${ }^{1}$, except that strontium chloride was used instead of sodium chloride. A large excess of carrier hæm was added in experiments $2,3,4$ and 6 but not in experiments 1 and 5 . In each experiment Table 1. EFFect of Copper on SYNTHesis OF HaM IN BLOOD

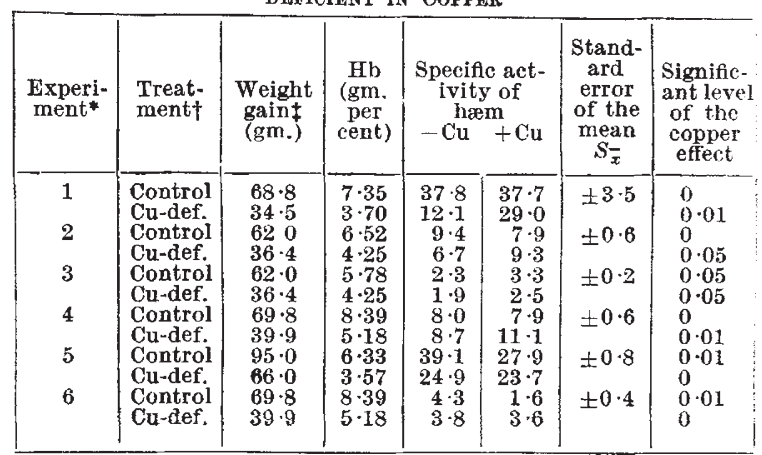

* Results in experiments 1,2 and 3 are from chicks fed carbonyl iron. Results in experiments 4,5 and 6 are from chicks fed iron chloride. diet.

$\ddagger$ The weight gains in experiment 5 are for four weeks and all other are for two weeks.

blood samples from 4-10 chicks were pooled and incubated either with or without supplemental copper sulphate to a final concentration of $1.6 \times 10^{-5} M$.

The results in Table 1 show that in blood from chicks deficient in copper and fed the diet containing carbonyl iron, synthesis of hæm was reduced, but the addition of copper to this blood consistently increased this synthesis. Blood obtained from chicks deficient in copper and fed iron chloride, however, gave an increased synthesis of hæm in the presence of copper only in experiment 4 . With the exception of experiment 3, the addition of copper to the blood from control chicks failed to increase the synthesis of hæm. 'This exception may possibly be related to the low concentration of hæmoglobin in the control chicks of this experiment.

The results obtained in these experiments demonstrate that copper has a direct function in the synthesis of hrm. From the fact that the copper effect was obtained consistently only when carbonyl irona source of iron of low availability-was used in the diet, it appears that a dual copper-iron deficiency may be essential to demonstrate the effect of copper on the in vitro synthesis of hæm.

Experiments are in progress to determine the site(s) of copper activity in the synthesis of ham. Recently, Iodice, Richert and Schulman ${ }^{3}$ have demonstrated that $\delta$-aminolævulinic acid dehydrase contains copper and that its activity is reduced in copper-deficiency. It is possible, however, that copper has functions in the synthesis of hæm other than in connexion with this enzyme and the system described here should prove beneficial in elucidating the role of copper in the synthesis of hæm.

We wish to thank Dr. C. H. Hill for providing the chicks used in these experiments and for his aid and advice in the care and feeding of them. This project was partially supported by a grant from the Frasch Foundation.

\section{R. L. ANDERSON}

S. B. Tove

Animal Nutrition Section,

Department of Animal Industry,

North Carolina State College,

Raleigh, North Carolina.

May 27.

${ }^{1}$ Shemin, D., London, J. M., and Rittenberg, D., J. Biol. Chem. 188, 757 ' (1950).

2Dresel, E. I. B., and Falk, J. E., Biochem. J., 83, 72 (1956),

3 Todice, A. A., Richert, D. V., and Schulman, M. P., Fed. Proc., 17. $248(1958)$. 